Hamed Ahmad Almahadin Yazan Oroud"

Recibido: 6 de agosto de 2019 Concepto de evaluación: 31 de octubre de 2019 Aprobado: 12 de diciembre de 2019

Artículo de investigación (c) 2019 Universidad Católica de Colombia. Facultad de Ciencias Económicas y Administrativas. Todos los derechos reservados

* PhD in Finance. Assistant Professor of Finance, Department of Banking and Finance, Applied Science Private University, Amman, Jordan. Email: h_almahadin@asu.edu.jo. (D) https://orcid.org/0000-0003-2129-0791.

$\mathrm{PhD}$ in Accounting. Assistant Professor of Accounting, Department of Accounting, Isra University, Amman, Jordan. Email: oroud.yazan@iu.edu.jo.

(D) https://orcid.org/0000-0003-0755-9854.
Finanz. polit. econ., ISSN: 2248-6046, Vol. 11, N. ${ }^{\circ}$ 2, julio-diciembre, 2019, pp. 375-386

http://doi.org/10.14718/revfinanzpolitecon.2019.11.2.9

\section{Capital Structure-Firm Value Nexus: The Moderating Role of Profitability}

\section{ABSTRACT}

This study aims to investigate the moderating role of profitability in the relationship between capital structure and firm value in Jordan, as an example of an emerging economy. For this purpose, two functional models were formulated to capture the direct relationship as well as the interaction impact of capital structure on firm value. The robust empirical findings of panel data analysis provide strong evidence of an adverse relationship between capital structure and firm value. The findings confirm that the impact of capital structure appears to be complicated in nature and difficult to examine without controlling for the interaction of profitability as one of the major determinants. Therefore, studying the interaction effect provides ample evidence and enhances the understanding of the link between firm value and capital structure. The empirical results of the study may provide important insights and policy implications to decision-makers.

Keywords: Capital structure, firm value, Jordan, moderating effect, panel analysis, profitability.

\section{JEL Classification: C33; E22; G10; G30; G32}

Cómo citar este artículo / To reference this article / Para citar este artigo:

Almahadin, H., A. \& Oroud, Y. (2019). Capital Structure-Firm Value Nexus: The Moderating Role of Profitability. Revista Finanzas y Politica Económica, 11 (2), 375 386. doi: http://dx.doi.org/10.14718/revfinanzpolitecon.2019.11.2.9

\section{Relación entre la estructura del capital y el valor de la empresa: el papel moderador de la rentabilidad}

\section{RESUMEN}

Este estudio tiene como objetivo investigar el papel moderador de la rentabilidad en la relación entre la estructura del capital y el valor de la empresa en Jordania como ejemplo de una economía emergente. Con este propósito en mente, se formularon dos modelos funcionales para entender la relación directa y el impacto de la interacción entre la estructura del capital y el valor de la empresa. Los sólidos resultados empíricos del análisis de datos 
de panel proporcionan una fuerte evidencia de una relación adversa entre la estructura del capital y el valor de la empresa. Los resultados confirman que el impacto de la estructura de capital parece ser de naturaleza complicada y difícil de examinar sin controlar la interacción de la rentabilidad como uno de los principales determinantes. Por lo tanto, estudiar el efecto de interacción no solo proporciona una amplia evidencia, sino también contribuye a un mejor entendimiento del vínculo entre el valor de la empresa y la estructura de capital. Los resultados empíricos del estudio pueden ofrecer importantes ideas e implicaciones políticas para los responsables de la toma de decisiones.

Palabras clave: análisis de panel, efecto moderador, estructura del capital, Jordania, rentabilidad, valor de la empresa.

\section{Relação entre a estrutura do capital e o valor da empresa: o papel moderador da rentabilidade}

\section{RESUMO}

Este estudo tem como objetivo pesquisar o papel moderador da rentabilidade na relação entre a estrutura do capital e o valor da empresa na Jordânia, como exemplo de uma economia emergente. A partir desse propósito, foram formulados dois modelos funcionais para entender a relação direta e o impacto da interação entre a estrutura do capital e o valor da empresa. Os sólidos resultados empíricos da análise de dados de painel proporcionam uma forte evidência de uma relação adversa entre a estrutura do capital e o valor da empresa. Além disso, confirmam que o impacto da estrutura do capital parece ser de natureza complexa e difícil de analisar sem controlar a interação da rentabilidade como um dos principais determinantes. Portanto, estudar o efeito da interação não somente possibilita uma ampla evidência, mas também contribui para entender melhor o vínculo entre a estrutura de capital e o valor da empresa. Os resultados empíricos deste estudo podem oferecer importantes ideias e apresentar consequências políticas para os responsáveis pela tomada de decisões.

Palavras-chave: análise de painel, efeito moderador, estrutura do capital, Jordânia, rentabilidade, valor da empresa. 


\section{INTRODUCTION}

Financing decisions constitute one of the most vital decisions for a corporation's chief financial officer. This decision-making involves an efficient mixing of different available financing sources (debt vs. equity) to minimize the weighted average cost of capital (WACC). Minimizing the WACC can increase economic returns, eventually positively affecting firm value (Groth \& Anderson, 1997). Constructing an optimal capital structure leads also to momentum in the development of firms. Moreover, capital structure combination is considered as a critical and strategic decision that has historically been observed to be puzzling (Kumar, Colombage \& Rao, 2017). Therefore, capital structure decisions dynamically affect firm value and are an essential and inextricable part of the stockholders' goal of wealth maximization.

The importance of incorporating capital structure decisions is first highlighted by the pioneering work of Modigliani and Miller (1958). The study argues that firm value is not affected by the combination of capital structure (irrelevant proposition); assets allocation (investment decisions) is the main determinants of firm value. The $M \& M$ proposition (1958) was developed under very restrictive assumptions, i.e.: (i) the capital market is perfect; (ii) the expectations of investors are homogenous; and (iii) there are neither taxes nor transaction costs. Under real market conditions, the suggestion of irrelevant proposition is unrealistic. In 1963, Modigliani and Miller developed their second proposition after including the benefits of tax shield, achieved by using debt in the capital structure. Based on this latest proposition, firm managers may prefer to use more debt to attain stockholders' wealth maximization as represented by firm value.

Subsequently, two theories have been developed to provide additional explanations about the capital structure-firm value relationship: the trade-off theory and the pecking order theory. These theories provide inconsistent views about the impact of capital structure combination on firm value
(Hamid, Abdullah \& Kamaruzzaman, 2015). The trade-off theory proposed by Jensen and Meckling (1976) demonstrates that financial managers in profitable companies, in general, prefer to finance their operating activities by debt, rather than by equity financing (Miller, 1977; Ahmad \& Abdul-Rahim, 2013). Based on this theory, firm managers tend to use more debt in their capital structure to maximize tax benefits compared to cost of financial distress (Nadaraja, Zulkafli \& Masron, 2011). Therefore, optimal capital structure depends on balancing both tax shield benefits and cost of financial distress. However, the pecking order theory of Myers and Majluf (1984) presumes that highly profitable companies tend to finance their activities with low level of debt. Based on this theory, financial managers prefer self-financing through retained earnings as a first priority compared to using borrowed funds, with the last resort being issuing equity instruments (Ting \& Lean, 2011).

In light of the contradicting arguments in theoretical and empirical studies, the present study suggests that the relationship between capital structure and firm value must be examined from another perspective, taking into consideration prior evidences showing that the study of the impact of capital structure decisions is complicated and difficult without controlling for the interaction of its major determinants. Therefore, this study investigates the moderating role of profitability in the capital structure-firm value relationship of the firms listed on the Amman Stock Exchange (ASE) in Jordan. To the best of the authors' knowledge, this is the first study that investigates the interaction of profitability in this relationship. Thus, the findings of the present study may provide important insights and policy implications for decision-makers.

Jordan is selected as an emerging economy of interest due to many reasons: Jordan's economy is one of the emerging economies in the Middle East region that has an underdeveloped financial market with limited financing channels. The country's financial system is bank-based, which means that the banking sector of Jordan plays a critical 
role in the economy and is a key source of funds for companies. At the same time, the limited number of banks in Jordan pose crucial challenges for financial managers to find the needed funds without restrictive conditions. With a relatively high tax rate compared to its neighboring countries, companies in Jordan tend to increase their indebtedness to achieve more tax benefits. And, finally, during the last decade, there were several political issues in the region that have affected the financial position of Jordanian firms.

The rest of this research paper is organized as follows: 1. Literature review is presented in section 2. Research methodology is summarized in section 3. Section 4 presents discussions of the empirical results. Finally, section 5 summarizes the main conclusions and policy implications.

\section{LITERATURE REVIEW}

Several empirical studies have argued about the role of capital structure in firm value. An unanswered question in this discussion is whether or not an individual firm has the optimal capital structure that can affect its market value. In other words, the purpose of these studies was to examine whether firm value is affected positively or negatively by the usage of debt compared to equity (Hatfield, Cheng \& Davidson, 1994). In this regard, Ross (1977) as well as Brealey, Leland and Pyle (1977) illustrated that firm value increases as the degree of leverage increases. Therefore, managers attempt to use optimal debt level to positively affect firm value; this is true in case of no conflict of interest between principal and agent. This point of view is confirmed also by Kochhar (1997) and Sander (2003): an individual firm can construct its optimal capital structure by efficient mixing of fund resources, which will positively influence firm value. A related study by Stulz (1990) founds inconsistent results; this study asserts that using debt among capital structure components may affect firm value in a bidirectional manner, either positively or negatively. In terms of capital structure influences, Pandey (2004) states that managers should pay considerable attention to capital structure decisions to attain the stockholders' wealth maximization goal.

From another perspective, a massive number of studies have examined the relationship between financial performance and capital structure. Among the various financial performance indicators, profitability gauges are used as proxies of financial performance, which are strongly associated with a firm's capital structure. Jensen and Meckling (1976) have argued about the possible association between capital structure and firm performance since 1976. In this respect, Kinsman and Newman (1999) illustrated that studying this relationship will have crucial implications for decision-makers and investors for many reasons: first, firms' debt level has increased sharply during the last few decades; second, there is an inherent possible conflict of interest between manager and principal regarding the appropriate degree of leverage; and finally, such a study can reveal critical signals about the shareholders' wealth maximization progress. Numerous researchers have provided mixed and inconsistent results about this relationship. For instance, a positive relationship is found by Ghosh and Jain (2000), Amran and Che Ahmad (2011), Ahmad and Abdul-Rahim (2013), and Hamid, Abdullah, and Kamaruzzaman (2015). All they asserted that using financial leverage is one of the main ways to improve the financial performance of levered companies. In contrast, Fama and French (1998), Simerly and Li (2000), and Nadaraja, Zulkafli \& Masron (2011) found an adverse relationship between capital structure and profitability. Ahmed et al. (2010) proposed that profitability is one of the main factors that influences capital structure decisions.

This literature review evidences a lack of studies on capital structure in emerging economies since the majority of studies have been done in the context of developed economies. In this regard, very few studies have tested the link between capital 
structure and profitability as proxies to measure the financial performance of firms in developing economies. For example, in Hong Kong, Yat Hung et al. (2002) found a positive relationship between financial leverage indicators and return on equity (ROE) as a measure of profitability. KyereboahColeman (2007) evinced the same relationship between the degree of financial leverage and ROE as well as return on assets (ROA), as measures of financial performance in sub-Saharan Africa. In Pakistan, Saleem et al. (2013) found a significant and positive impact of profitability on the capital structure of oil and gas firms listed on the Karachi Stock Exchange. Contrasting results on the relationship between capital structure and various profitability measurements were found by Majumdar and Chhibber (1999) in their study of Indian companies. In Jordan, Zeitun and Tian (2007) found a negative relationship between capital structure and financial performance, measured by market and accounting indicators. Finally, in the Republic of Mauritius, Ramlall (2009) confirmed the arguments of the pecking order theory about an inverse relationship between capital structure and profitability, which is attributed to a preference for internal self-financing over borrowed funds.

\section{RESEARCH METHODOLOGY}

\section{Sampling and data collection}

In this study, the sample includes all firms listed on the ASE during the period of 2013-2017, except for banks and insurance companies. This period was chosen as it provides the most recent available data. A total of 213 firms were listed on the ASE during the period of the study with a total of 1065 observations. Similar to earlier studies, secondary financial data is the main source, gathered from the annual reports of listed companies available on the ASE website. It is argued that secondary data is more suitable than primary data as it is usually permanent, available, and can be easily checked (Denscombe, 2008).

\section{Research framework}

As mentioned above, many studies have investigated the relationship between capital structure and firm value (e.g., Modigliani \& Miller, 1958, 1963; Miller, 1977; Myers \& Majluf, 1984; Fama \& French, 1998; Ting \& Lean, 2011; Kumar, Colombage \& Rao, 2017).

Figure 1.

Research Framework

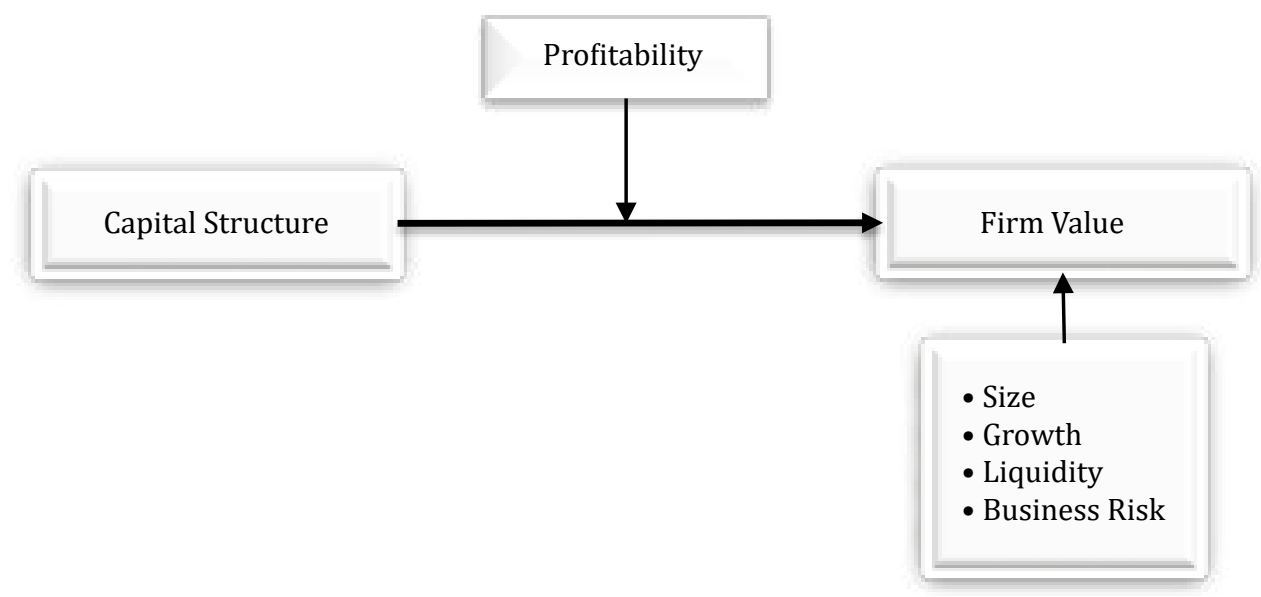

Source: Author's elaboration. 
However, to the best of our knowledge, very few studies have looked into a possible interaction of profitability as a moderator in the capital structure-firm value relationship. Thus, the present study attempts to contribute to the body of knowledge by considering the moderating effect of profitability in this relationship, as represented in Figure 1.

\section{Variables measurement}

In this study, firm value is measured by Tobin's $Q$ ratio. Capital structure is gauged by debt ratio, while profitability is measured by operating profits to assets, which is calculated as earnings before interest and tax (EBIT) over total assets. In order to capture the influence of other factors, the study used a set of control variables, i.e., size of firm, measured by the natural logarithm of assets; growth, measured by market-to-book ratio; liquidity, measured by current ratio; and business risk, measured by the standard deviation (SD) of EBIT. The abbreviations and measurements of variables are represented in Table.1.

\section{Research models and analysis techniques}

This research is based on two functional models. The first one is presented in Equation 1 to examine the direct impact of capital structure on firm value:

$V_{i t}=\alpha+\beta_{1} D B_{i t}+\beta_{2} S_{i t}+\beta_{3} G R_{i t}+\beta_{2} L Q_{i t}$

$+\beta_{3} B R_{i t}+\varepsilon_{i t}$
Where $V$ (Firm Value), $D B$ (Capital Structure), $S$ (Firm Size), GR (Growth), $L Q$ (Liquidity), $B R$ (Business Risk), $\alpha$ (intercept term), $\beta$ 's are coefficients to be estimated, and $\varepsilon$ is the estimate error term for each firm ( $i$ ) and each year $(t)$.

The second model, Equation 2, explains the role of profitability as a moderator variable in the capital structure-firm value relationship:

$V_{i t}=\alpha+\beta_{1} D B_{i t}+\beta_{2} P R O F_{i t}+\beta_{3}\left(D B^{*} P R O F\right)_{i t}$ $+\beta_{4} S_{i t}+\beta_{5} G R+\beta_{6} L Q_{i t}+\beta_{7} B R_{i t}+\varepsilon_{i t}$

Where $V$ (Firm Value), $D B$ (Capital Structure), PROF (Profitability), $S$ (Firm Size), GR (Growth), $L Q$ (Liquidity), $B R$ (Business Risk), $\alpha$ (intercept term), $\beta$ 's are coefficients to be estimated, and $\varepsilon$ is the estimate error term for each firm (i) and each year $(t)$.

A panel data analysis is adopted to examine the main functional models, which is the most commonly used analysis in accounting and finance studies. Panel data, also known as cross-sectional time-series data or longitudinal data, is typically represented by data about several individual aspects observed over a period of time. Therefore, panel data observations usually include a minimum of two aspects: a time-series dimension represented by $t$; and a cross-sectional dimension represented by $i$ (Hsiao, 2003). In this type of analysis, a fixed-effects or a random-effects model is applied to control for heterogeneity in panel data regression (Wooldridge, 2010). Baddeley and Barrowclough (2009) as well as Wooldridge (2010) explained the importance of taking into consideration the individual factors of panel data observations, which remain constant

Table 1.

\section{Measurement of Variables}

\begin{tabular}{|c|c|c|}
\hline Variables & Acronym & Measurement \\
\hline Firm Value & $V$ & Tobin's Q Ratio \\
\hline Capital Structure & $D B$ & Total debt/total assets \\
\hline Profitability & $P R O F$ & LBIT Total Assets \\
\hline Firm Size & $S$ & Market Value / Book Value \\
\hline Growth & $G R$ & Current Ratio \\
\hline Liquidity & $L Q$ & SD of EBIT \\
\hline Business Risk & $B R$ & \\
\hline
\end{tabular}

Source: Authors' calculations. 
over time and cannot be assumed as independently distributed across time, whereas pooled ordinary least squares (OLS) estimation may introduce bias in the results, which then can lead to incorrect inferences and cannot be applied to panel data. In pooled OLS, firm-specific factors are not considered when applied to panel data, which results in autocorrelation as there is no isolation between years in the same firm. Also, it could result in omitted variables bias and heterogeneity bias because observations could have similar characteristics that are not considered (Baddeley \& Barrowclough, 2009). Therefore, the influence of capital structure on firm value is one of the issues that needs to be studied using panel data analysis (Donker, Poff \& Zahir, 2008).

\section{EMPIRICAL RESULTS}

In general, the Hausman test compares fixed-effects to random-effects coefficients to decide which model is appropriate. If the $p$-value is significant, then the fixed-effects model should be applied since using random-effects would be biased. However, if the $p$ value is insignificant, random-effects can be safely used (Wooldridge, 2010). In the current study, the Hausman test was applied to the two models and the results show significant $p$-values for both models, which means that a fixed-effects model should be adopted. In panel data, even if the variance of errors is constant between cross-sectional observations, it may differ within observations through time, which raises the issue of groupwise heteroscedasticity (Baum, 2001). According to Baltagi (2008), ignoring the presence of heteroscedasticity can result in inefficient coefficient estimations and biased standard errors. Accordingly, the modified Wald test for groupwise heteroscedasticity is used to check the existence of the heteroscedasticity problem. With regard to the heteroscedasticity problem in tested models, the robust covariance matrix estimation of Driscoll and Kraay (1998) is employed to correct and avoid this problem. Thus, robust results are presented after controlling for the possibility of existing heteroscedasticity problem.

The direct impact of capital structure on firm value of Model 1 was tested and the empirical outcomes are reported in Table 2 . The estimations show that capital structure negatively affects firm value at significance level of 10 percent with estimated coefficient value of -2.45 ; this result is consistent with Stulz (1990). Furthermore, the estimated coefficients of control variables demonstrate that firm size and growth have a positive and significant impact on firm value. Kumar, Colombage and Rao (2017) postulated that firm size and growth seem to have a positive impact on firm value as it is believed that larger firms with higher growth tend to have more financing flexibility as they enjoy economies of scale. In contrast, business risk negatively affects firm value at significance level of 0.05 . Firms with volatile returns may have financing disability that

Table 2.

Empirical Outcomes of Model 1

\begin{tabular}{|c|c|c|c|}
\hline \multicolumn{4}{|c|}{$V_{i t}=\alpha+\delta \mathrm{i}+\beta_{1} D R_{i t}+\beta_{2} S_{i t}+\beta_{3} G_{i t}+\beta_{4} B R_{i t}+\beta_{5} L Q_{i t}+\varepsilon_{\mathrm{t}}$} \\
\hline Variables & $\boldsymbol{\beta}$ & $\boldsymbol{t}$ & $\boldsymbol{P}>\mid \boldsymbol{t} /$ \\
\hline Capital Structure & -2.450 & -1.86 & $0.063^{*}$ \\
\hline Size & 2.581 & 3.96 & $0.000^{* * *}$ \\
\hline Growth & 2.182 & 3.58 & $0.000^{* * *}$ \\
\hline Business Risk & -0.292 & -2.02 & $0.044^{* *}$ \\
\hline Liquidity & -0.093 & -0.86 & 0.387 \\
\hline Constant & -15.605 & -3.22 & $0.001^{* * *}$ \\
\hline \multicolumn{2}{|c|}{} & & $F=22.31^{* * *}$ \\
\hline
\end{tabular}

Notes: Significance level *** 1\%,** 5\%, and * 10\%

Source: Author's calculations. 
limits their fund resources, which, at the same time, adversely affects the market value of their stocks. Regarding the diagnostics of the overall model, the $F$-test indicates that the estimated model is suitable at the significance level of 0.01 , and the $R$-square is approximately 32 percent.

Based on prior studies by Cohen \& Wills (1985) and Zhou et al. (2014), using moderator variable(s) in case of inconsistent results will lead to superior empirical outcomes. The estimated interaction of profitability as a moderator variable in the relationship between capital structure and firm value is summarized in Table 3. Compared to the estimations of Model 1, capital structure still negatively affects firm value with a higher coefficient value of -4.0, indicating a greater adverse impact on firm value. The significance level of this coefficient is 0.01 , which is much better than the significance level of the same variable when estimated in Model 1. This can be attributed to a moderator variable being used to capture the interaction effect. The moderator factor of profitability with debt ratio adversely affects firm value by an estimated coefficient value of -10.80 at strong significance level of 0.01 . This result confirms the opposite role of debt in firm value performance; as the degree of indebtedness increases, the firm value of the sampled firms decreases. These results can be explained more clearly using the trade-off theory; companies should have an optimal capital structure that can minimize the
WACC and thus maximize firm value. This theory demonstrates that companies must have optimal capital structure with appropriate degree of leverage; as the amount of borrowed funds increases compared to other elements in the capital structure, firm value is adversely influenced.

Besides estimations of profitability, size and growth have a positive and significant effect on firm value. The highest estimated coefficient value is recorded at 3.83 for profitability. This indicates that Jordanian firms are influenced positively by increasing profitability. In other words, increasing profitability will be followed by an increase in the firm value of Jordanian firms. Current and prospective investors prefer profitable firms for investment; this creates continuous and stable demand for their stocks, which positively reflects on the market value of the stocks. Regarding the positive impacts of firm size and growth, the empirical outcomes indicate that firm size and growth are positive signals for investors, thereby resulting in an increase in firm value. In contrast, the coefficient of business risk is negative and strongly significant. This result reveals the negative signaling of earnings volatility; investors are reluctant to hold or to buy stocks of volatile companies with earnings uncertainty, which then adversely affects firm value.

Based on the above results, it is clear that the estimated coefficient values and significance levels are better in the second model compared to the first one.

Table 3.

Empirical Outcomes of Model 2

\begin{tabular}{|c|c|c|c|}
\hline \multicolumn{3}{|c|}{$V_{i t}=\alpha+\delta i+\beta_{1} D R_{i t}+\beta_{2} P R O F_{i t}+\beta_{3}\left(D R^{*} P R O F\right)_{i t}+\beta_{4} S_{i t}+\beta_{5} G_{i t}+\beta_{6} B R_{i t}+\beta_{7} L Q_{i t}+\varepsilon_{t}$} \\
\hline Variables & $\boldsymbol{\beta}$ & $\boldsymbol{t}$ & $\boldsymbol{P}>|\boldsymbol{t}|$ \\
\hline Capital Structure & -4.000 & -2.80 & $0.005^{* * *}$ \\
\hline Profitability & 3.831 & 2.30 & $0.021^{* *}$ \\
\hline Moderator\# & -10.800 & -2.74 & $0.006^{* * *}$ \\
\hline Size & 3.030 & 4.42 & $0.000^{* * *}$ \\
\hline Growth & 2.230 & 3.66 & $0.000^{* * *}$ \\
\hline Business Risk & -0.267 & -1.85 & $0.064^{*}$ \\
\hline Liquidity & -0.110 & -1.01 & 0.311 \\
\hline Constant & -18.448 & -3.65 & $0.000^{* * *}$ \\
\hline \multicolumn{2}{|c|}{} \\
\hline
\end{tabular}

Notes: Significance level ${ }^{* * *} 1 \%$, ${ }^{* *} 5 \%$, and $* 10 \%$

Source: Author's calculations. 
This can be attributed to the inclusion of the moderator variable of profitability in the model. The overall model is fit at 0.01 level of confidence and the value of $R$-square is 34 percent. The stronger results can be attributed to the moderator variable, which gives more support to the main contribution of the present study. To sum up, the interaction effect of profitability with debt ratio as a combined factor has a simultaneous effect on the dependent variable (firm value). Studying the interaction effect of these factors provides ample evidence and better understanding of the link between firm value as dependent variable and capital structure as independent variable.

\section{CONCLUSION AND POLICY IMPLICATIONS}

The present study investigates the relationship between capital structure and firm value with profitability playing a moderating role. The sample comprises 213 firms listed on the ASE during the period of 2013-2017. A fixed-effects panel data analysis was used. The basic argument of the study is that capital structure decisions are puzzling, complicated in nature, and difficult to examine without controlling for the interaction of its major determinants (profitability and debt ratio). There have been several contradictory findings in theoretical and empirical studies. Therefore, studying the interaction effect of profitability with debt ratio as a combined factor on firm value is necessary to capture the possible simultaneous effect of these factors on firm value.

The empirical outcomes reveal that the firm value of Jordanian firms is negatively influenced by debt ratio as a measure of capital structure combination. This result, together with high indebtedness observed in data, indicates that the studied firms in Jordan have no optimal capital structure. In this regard, these firms may be using heavy debt in order to finance their operating activities without considering the impact of this policy on firm value. As it is well-known, using more borrowed funds indicates increasing financial leverage as well as increasing risk of bankruptcy. This, in turn, will send negative signals to lenders and investors. Lenders will be reluctant to provide more loans to these companies without restrictive conditions and higher fixed charge payments, especially in case of underdeveloped capital markets and limited numbers of banks as in Jordan. Also, current and prospective investors will have less incentives to buy shares of heavy debt companies; this will then lead to less demand and more supply, resulting in the fall of share prices.

The findings of the study provide critical financial insights and policy implications for practitioners. Capital structure combination is a critical issue that must be seriously considered in the accounts of a company. This combination is a crucial factor that has direct and indirect influences on the financial position of a firm, which eventually will be reflected in firm value. Thus, financial managers must efficiently mix their capital structure to reach optimal combination so as to maximize stockholders' wealth. They should also obtain momentum and continuous profitability, size, and growth trends, in order to positively affect firm value. At the same time, financial officers should achieve earnings persistence, which eliminates the impact of bad signalling from the business risk indicator. As for current and prospective investors, they must assess the overall financial position of firms without focusing their attention on a minor issue, such as debt position.

\section{ACKNOWLEDGMENT}

The corresponding author is grateful to the Applied Science Private University, Amman, Jordan, for the financial support granted to this research project. The second author is grateful to Isra University for the financial reward granted to this research. 


\section{REFERENCES}

1. Ahmad, N. \& Abdul-Rahim, F. (2013). Theoretical investigation on determinants of government-linked companies capital structure. Journal of Accounting, Finance and Economics, 3(2), 72-85.

2. Ahmed, N., Ahmed, Z. \& Ahmed, I. (2010). Determinants of capital structure: A case of life insurance sector of Pakistan. European Journal of Economics, Finance and Administrative Sciences, 24(24), 7-12. https:// doi.org/10.22495/rcgv6i4c1art13

3. Amran, N.A. \& Che Ahmad, A. (2011). Board mechanisms and Malaysian family companies' performance. Asian Journal of Accounting and Governance, 2, 15-26. https://doi.org/10.17576/ajag-2011-2-6538

4. Baddeley, M.C. \& Barrowclough, D.V. (2009). Running Regressions: A Practical Guide to Quantitative Research in Economics, Finance and Development Studies. Cambridge: Cambridge University Press. https:// doi.org/10.1017/CBO9780511814839

5. Baltagi, B. (2008). Econometric analysis of panel data. John Wiley \& Sons.

6. Baum, C.F. (2001). Residual diagnostics for cross-section time series regression models. The Stata Journal, 1(1), 101-104. https://doi.org/10.1177/1536867X0100100108

7. Brealey, R., Leland, H.E. \& Pyle, D.H. (1977). Informational asymmetries, financial structure, and financial intermediation. The Journal of Finance, 32(2), 371-387. https://doi.org/10.1111/j.1540-6261.1977.tb03277.x https://doi.org/10.2307/2326770

8. Cohen, S. \& Wills, T.A. (1985). Stress, social support, and the buffering hypothesis. Psychological Bulletin, 98(2), 10. https://doi.org/10.1037/0033-2909.98.2.310

9. Denscombe, M. (2008). Communities of practice: A research paradigm for the mixed methods approach. Journal of Mixed Methods Research, 2(3), 270-283. https://oi.org/10.1177/1558689808316807

10. Donker, H., Poff, D. \& Zahir, S. (2008). Corporate values, codes of ethics, and firm performance: A look at the Canadian context. Journal of Business Ethics, 82 (3), 527-537. https://doi.org/10.1007/s10551-007-9579-x

11. Driscoll, J.C. \& Kraay, A.C. (1998). Consistent covariance matrix estimation with spatially dependent panel data. Review of Economics and Statistics, 80 (4), 549-560. https://doi.org/10.1162/003465398557825

12. Fama, E.F. \& French, K.R. (1998). Taxes, financing decisions, and firm value. The Journal of Finance, 53(3), 819-843. https://doi.org/10.1111/0022-1082.00036

13. Ghosh, A. and Jain, P.C. (2000). Financial leverage changes associated with corporate mergers. Journal of Corporate Finance, 6(4), 377-402. https://doi.org/10.1016/S0929-1199(00)00007-9

14. Groth, J.C. \& Anderson, R.C. (1997). Capital structure: perspectives for managers. Management Decision, 35(7), 552-561. https://doi.org/10.1108/00251749710170529

15. Hamid, M.A., Abdullah, A. \& Kamaruzzaman, N.A. (2015). Capital structure and profitability in family and non-family firms: Malaysian evidence. Procedia Economics and Finance, 31, 44-55. https://doi. org/10.1016/S2212-5671(15)01130-2

16. Hatfield, G.B., Cheng, L.T. \& Davidson, W.N. (1994). The determination of optimal capital structure: The effect of firm and industry debt ratios on market value. Journal of Financial and Strategic Decisions, 7(3), 1-14.

17. Hsiao, C. (2003). Analysis of panel data (Vol. 34). Econometric Society Monographs. https://doi.org/10.1017/ CBO9780511754203

18. Jensen, M.C. \& Meckling, W.H. (1976). Theory of the firm: Managerial behavior, agency costs and ownership structure. Journal of Financial Economics, 3(4), 305-360. https://doi.org/10.1016/0304-405X(76)90026-X 
19. Kinsman, M. \& Newman, J. (1999). Debt level and firm performance: an empirical evaluation. Paper presented at the 28th Annual Meeting of the Western Decision Science Institute. Puerto Vallarta, Mexico.

20. Kochhar, R. (1997). Strategic assets, capital structure, and firm performance. Journal of Financial and Strategic Decisions, 10(3), 23-36. http://www.financialdecisionsonline.org/archive/pdffiles/v10n3/kochhar.pdf

21. Kumar, S., Colombage, S. \& Rao, P. (2017). Research on capital structure determinants: a review and future directions. International Journal of Managerial Finance, 13(2), 106-132. https://doi.org/10.1108/ IJMF-09-2014-0135

22. Kyereboah-Coleman, A. (2007). The impact of capital structure on the performance of microfinance institutions. The Journal of Risk Finance, 8(1), 6-71. https://doi.org/10.1108/15265940710721082

23. Majumdar, S.K. \& Chhibber, P. (1999). Capital structure and performance: Evidence from a transition economy on an aspect of corporate governance. Public Choice, 98(3-4), 287-305. https://doi. org/10.1023/A:1018355127454

24. Miller, M.H. (1977). Debt and taxes. The Journal of Finance, 32(2), 261-275. https://doi.org/10.2307/2326758 https://doi.org/10.1111/j.1540-6261.1977.tb03267.x

25. Modigliani, F. \& Miller, M.H. (1958). The cost of capital, corporation finance and the theory of investment. The American Economic Review, 48(3), 261-297. https://gvpesquisa.fgv.br/sites/gvpesquisa.fgv.br/ files/arquivos/terra__the_cost_of_capital_corporation_finance.pdf

26. Myers, S.C. \& Majluf, N.S. (1984). Corporate financing and investment decisions when firms have information that investors do not have. Journal of Financial Economics, 13(2), 187-221. https://doi. org/10.1016/0304-405X(84)90023-0

27. Nadaraja, P., Zulkafli, A.H. \& Masron, T.A. (2011). Family ownership, firm's financial characteristics and capital structure: evidence from public listed companies in Malaysia. Economia Seria Management, 14(1), 141-155. https://ideas.repec.org/a/rom/econmn/v14y2011i1p141-155.html

28. Pandey, I.M. (2004). Capital structure, profitability and market structure: Evidence from Malaysia. Asia Pacific Journal of Economics and Business, 8(2), 78.

29. Ramlall, I. (2009). Determinant of capital structure among non-quoted Mauritian firms under specificity of leverage: Looking for a modified pecking order theory. International Research Journal of Finance and Economics, 31(31), 83-92.

30. Ross, S.A., (1977). The determination of financial structure: the incentive-signalling approach. The Bell Journal of Economics, 23-40. https://doi.org/10.2307/3003485

31. Saleem, F., Rafique, B., Mehmood, Q., Irfan, M., et al. (2013). The determination of capital structure of oil and gas firms listed on Karachi stock exchange in Pakistan. Interdisciplinary Journal of Contemporary Research in Business, 4(9), 225-235. https://journal-archieves27.webs.com/225-235.pdf

32. Sander, P. (2003). Capital Structure Choice in Estonian Companies: A Survey. Management of Organizations: Systematic Research, 27.

33. Simerly, R.L. \& Li, M. (2000). Environmental dynamism, capital structure and performance: a theoretical integration and an empirical test. Strategic Management Journal, 21(1), 31-49. https://doi.org/10.1002/ (SICI) 1097-0266(200001)21:1<31::AID-SMJ76>3.0.CO;2-T

34. Stulz, R. (1990). Managerial discretion and optimal financing policies. Journal of Financial Economics, 26(1), 3-27. https://doi.org/10.1016/0304-405X(90)90011-N 
35. Ting, I.W.K. \& Lean, H.H. (2011). Capital structure of government-linked companies in Malaysia. Asian Academy of Management Journal of Accounting EF Finance, 7(2). http://web.usm.my/journal/aamjaf/vol\%20 7-2-2011/7-2-6.pdf

36. Wooldridge, J.M. (2010). Econometric analysis of cross section and panel data. MIT Press.

37. Yat Hung, C., Ping Chuen Albert, C., \& Chi Man Eddie, H. (2002). Capital structure and profitability of the property and construction sectors in Hong Kong. Journal of Property Investment $\mathcal{E}$ Finance, 20(6), 434-453. https://doi.org/10.1108/14635780210446469

38. Zhou, Y., Tsang, A.S., Huang, M., \& Zhou, N. (2014). Group service recovery strategies effectiveness: The moderating effects of group size and relational distance. Journal of Business Research, 67(11), 2480-2485. https://doi.org/10.1016/j.jbusres.2014.03.008 